\title{
CHARACTERIZATION OF SUBABUL HEARTWOOD AND SAPWOOD PULPS AFTER COOKING AND BLEACHING
}

\author{
MADHURI PYDIMALLA, NIKHIL SAINATH REDDY and RAMESH BABU ADUSUMALLI \\ Department of Chemical Engineering, Hyderabad Campus, BITS, Pilani, \\ Hyderabad 500078, India \\ $₫$ Corresponding author: Ramesh B. Adusumalli,ramesh.babu@hyderabad.bits-pilani.ac.in
}

Received September 9, 2018

\begin{abstract}
This study aimed to investigate the effect of cooking temperature $\left(165{ }^{\circ} \mathrm{C}, 140{ }^{\circ} \mathrm{C}\right)$ on subabul heartwood and sapwood pulps separately, and the effect of bleaching on the mixed subabul wood pulp. The pulps cooked at $165^{\circ} \mathrm{C}$ had high cellulose content, high water retention value and low lignin content, compared to those obtained at $140{ }^{\circ} \mathrm{C}$. Microscopic analysis confirmed the integrity of the pulps obtained at $140{ }^{\circ} \mathrm{C}$, while those cooked at $165{ }^{\circ} \mathrm{C}$ presented loose and collapsed fibres. The water retention value and the cellulose and ash contents of sapwood pulp were much higher in comparison to those of heartwood pulp, for both temperatures, and it could be due to the differences in their lignin and extractive contents. Bleached pulp had high cellulose content, high brightness and was thermally stable up to $300{ }^{\circ} \mathrm{C}$. For packaging applications requiring processing temperatures of up to $600{ }^{\circ} \mathrm{C}$, unbleached fibres are recommended due to the integrity of their cell wall. UV-visible spectroscopy data revealed that $2 \mathrm{~h}$ cooking time was sufficient for effective removal of lignin from the heartwood, but the situation was different in the case of sapwood.
\end{abstract}

Keywords: heartwood, sapwood, kraft cooking, bleaching, Klason lignin, black liquor

\section{INTRODUCTION}

Wood is one of the most important raw materials for paper-making, apart from non-wood fibres (bagasse, cotton, wheat straw). Wood cells are bonded to each other by a compound middle lamella, which is rich in lignin. The wood cell, of 20-60 $\mu \mathrm{m}$ thick, is a complex anisotropic fibre composed of cell wall (thickness of 2-10 $\mu \mathrm{m}$ ) and lumen. ${ }^{1}$ The cell wall is considered as a nanocomposite, wherein cellulose microfibrils are reinforced in the lignin matrix and the resulting "cellulose-hemicellulose-lignin" composite becomes so strong that the lignin cannot be removed alone, without any damage to the cellulose. ${ }^{1}$ Lignin is covalently linked to hemicellulose and cellulose and it is a thermoset polymer with a three-dimensional network, composed of phenyl propane units. ${ }^{2}$ Lignin is commonly known as a binding agent holding the cellulose fibres together and it is hydrophobic. ${ }^{2-3}$ In most of the tropical and subtropical woods, cellulose, hemicellulose and lignin account for $90 \%$ of the mass, whereas the low molecular weight components, such as extractives and inorganic substances, represent the remaining $10 \%$, as a rough approximation. ${ }^{3}$ The ash content can be up to $5 \%$ in these hardwood species. ${ }^{4}$ The cross-section of wood has two concentric regions, i.e. heartwood and sapwood, which are physiologically different, ${ }^{5-6}$ as shown in Figure 1a. Some xylem cells in the tree are known as living cells and form the light colour wood, occupying $\sim 40 \%$ of the outer region of the wood (inside the bark), which is called sapwood. ${ }^{7}$ After an indefinite length of time, the protoplasm of the living cells in the xylem becomes physiologically inactive, thereby converting sapwood into heartwood. ${ }^{8}$ The heartwood is mostly darker in colour, compared to the sapwood, due to the deposition of resinous organic compounds, extractives etc. in the cell walls and cavities. ${ }^{9}$ The sapwood portion acts as a storage reservoir and provides the important function of water conduction. Heartwood provides mechanical support and is formed from a concentration of dead cells in the central part of tree stems/trunk, after a certain age or under certain conditions. ${ }^{10}$ Glucose, fructose and sucrose are the main sugars present in sapwood and their content sharply decreases when sapwood - heartwood transition happens. ${ }^{11}$ Heartwood has more lignin, less 
cellulose and less pentosan than sapwood. ${ }^{12}$ On the other hand, the extractives and mineral content of heartwood is higher than that of sapwood. $^{13}$

A major objective in paper manufacture is to remove the lignin from wood, by either mechanical or chemical methods. Chemical processes involve the effective removal of lignin from cell interfaces (compound middle lamella) by kraft cooking and the removal of residual lignin from cell walls by bleaching, thus resulting in high strength pulp fibres, which are rich in cellulose. $^{14}$ The kraft process, which uses $\mathrm{NaOH}$ and $\mathrm{Na}_{2} \mathrm{~S}$, has three distinct stages: the initial, bulk and residual delignification phases. ${ }^{14}$ During the initial delignification stage, wood chips are impregnated with cooking liquor and the temperature is elevated up to $140{ }^{\circ} \mathrm{C}$. ${ }^{15}$ At this stage, $15-25 \%$ of the lignin is removed, but the selectivity is low. In the bulk delignification stage, the cooking temperature exceeds $140{ }^{\circ} \mathrm{C}$, accelerating the depolymerisation of lignin present in middle lamella regions and also from cell wall regions, due to which $\sim 90 \%$ of the lignin is removed from chips. During the residual delignification stage, the depolymerisation of cellulose increases notably and delignification decreases, i.e. only $10 \%$ of the lignin (based on the residual lignin content present at the beginning of the residual delignification) is removed. $^{14}$
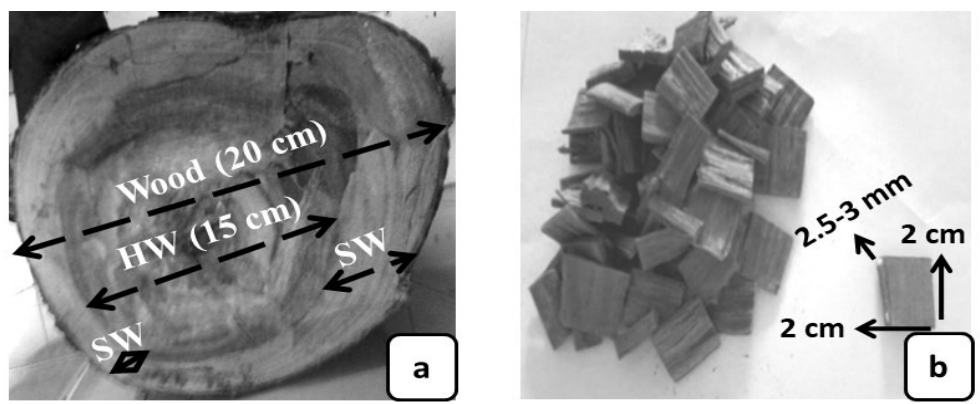

Figure 1: a) Cross-section of subabul wood log, revealing heartwood and sapwood; b) subabul wood chips prior to kraft cooking (HW - heartwood, SW - sapwood)

Unbleached kraft pulps have a dark brown colour due to a large amount of chromophores present in the pulp, mainly found in the residual lignin. ${ }^{9}$ The primary goal of bleaching is to remove the residual lignin without much degradation of cellulose (slight decrease in viscosity and strength) and also to increase the brightness of the pulp. ${ }^{14}$ As a result of cooking, bleaching and subsequent beating, pulp fibres collapse (reduction in lumen size) and flatten in shape, compared to native wood fibres. ${ }^{4}$ Black liquor, the spent pulping liquor, is separated from the pulp after the cooking process. ${ }^{16}$ It contains dissolved lignin and other alkali soluble organic matter, as well as inorganic components of white liquor. ${ }^{17}$ Lignin is degraded to shorter fragments with sulphur content of $1-2 \%$ and sodium content of about $6 \%$ of the dry solids. ${ }^{18}$ Cellulose and hemicellulose are degraded to aliphatic carboxylic acid soaps and hemicellulose fragments. ${ }^{19}$ The changes in the composition of the raw material after pre-treatment and cooking can significantly change the characteristics of the black liquor, therefore it is necessary to evaluate the black liquor characteristics simultaneously with the pulp characteristics to find out the effect of cooking temperature and time.

Lourenco et al. $^{20}$ compared Eucalyptus globulus heartwood pulp with sapwood pulp at three different kraft cooking temperatures (i.e. $130{ }^{\circ} \mathrm{C}, 150{ }^{\circ} \mathrm{C}$ and $170{ }^{\circ} \mathrm{C}$ ) and found differences between the two pulps owing to lower yields and higher content of extractives. Residual lignin of $2 \%$ and $1.1 \%$ for heartwood and sapwood pulps, respectively, was reported after $180 \mathrm{~min}$ of cooking at $170{ }^{\circ} \mathrm{C}$. Similarly, Miranda et al., ${ }^{21}$ Morais et al., ${ }^{22}$ and Miranda et $a .^{23}$ concluded that there is a strong relation between the extractives content and the heartwood proportion in wood, which contributes to the potential loss of pulp yield (heartwood pulps resulted in lower yields, compared to sapwood) and problems 
associated with the accumulation of extractives (directly related to the heartwood proportion). Therefore, the presence of heartwood in wood logs decreases the quality of the raw material used for pulping, in the case of Eucalyptus globulus trees. For softwoods (pine), Esteves et al. ${ }^{24}$ reported chemical differences between heartwood and sapwood, in particular, the extractives content (19.7\% for heartwood and 5.8\% for sapwood). Atac et $\mathrm{al}^{25}$ examined the differences between heartwood and sapwood chemical pulps, indicating that heartwood pulps had shorter fibre length, lower pulp viscosity, lower pulp yield and higher extractives content, compared to sapwood pulps. Neto et $a .^{26}$ investigated the effect of Eucalyptus globulus kraft pulping conditions on the chlorine dioxide consumption in elemental chlorine free bleaching. The studies also concluded that the pulping parameters, namely active alkali, sulfidity, temperature and liquor-towood ratio significantly affected the bleachability of the pulps subjected to a conventional elemental chlorine free (DEDED; D stands for chlorine dioxide and $\mathrm{E}$ stands for alkaline extraction) bleaching sequence.

Intensive efforts mounted by paper mills, including ITC Limited (leading manufacturer in India), have led to the plantation of wood species on about 900,000 ha all over India, covering majorly subabul, eucalyptus and casuarina, which is meeting the demand of 9.83 million tonnes of wood by Indian paper industry. Even though eucalyptus and subabul are commonly used raw materials for paper production in India, limited information is available about the effect of heartwood content on kraft cooking and bleaching processes of subabul wood. Very few studies focused on a systematic study of lignin determination after cooking and bleaching by testing wood, pulp and black liquor properties simultaneously. Researchers have concentrated on the cooking (digestion) process, but an elaborate study on the lignin content of pulp before cooking, after cooking and after bleaching, as well as on the correlation of temperature and wood species, has not been reported. Therefore, this study focuses on the impact of the kraft cooking process and bleaching on subabul wood (whole wood, heartwood and sapwood), using two different temperatures $\left(140{ }^{\circ} \mathrm{C}, 165^{\circ} \mathrm{C}\right)$ and three different cooking times $(1 \mathrm{~h}, 2 \mathrm{~h}, 3 \mathrm{~h})$. To investigate the differences between the pulps, they were characterised in terms of water retention value, cellulose content, ash content and lignin content, as well as by optical microscopy and thermogravimetric analysis.

\section{EXPERIMENTAL \\ Raw materials}

The raw material, subabul wood (Leucaena leucocephala) (common names: Huaxin, Ipil-ipil, White lead tree, Guaje, Yin-hue-whan, Reuse-wattle and Lamtoro), used in this study was obtained from Kandukoor area, Ranga Reddy Dist, Hyderabad, India. The log selected was 7-8 years of age and was cut $3 \mathrm{ft}$ above the ground level and it was $1 \mathrm{~m}$ long and $20 \mathrm{~cm}$ in diameter. Around $60 \%$ of the inner cross-sectional area was considered as heartwood and the remaining was considered as sapwood (Fig. 1a). Sapwood and heartwood were separated using a wood turning machine and were further cut down to chips of $2 \mathrm{~cm} \mathrm{x}$ $2 \mathrm{~cm} \times 2.5-3 \mathrm{~mm}$ dimensions (Fig. 1b) with the help of a chisel. The wood chips were dried at $103.5^{\circ} \mathrm{C}$ in a hot air oven (Osworld OOG-90) to remove the bound moisture. The chips (whole wood, heartwood, sapwood) were subjected to pre-treatment at $120{ }^{\circ} \mathrm{C}$ for $1 \mathrm{~h}$ in an autoclave (Metalab MSI-41) to soften the lignin present in the middle lamella and to remove the organic extractives. Steaming at $120{ }^{\circ} \mathrm{C}$ also enables the chips to be more accessible to the white liquor owing to the creation of pore channels due to the removal of trapped air.

\section{Kraft cooking (delignification) of wood chips}

The delignification process was carried out in a Rotary pulp digester (UEC-2015, Saharanpur, India). The reaction mixture of white liquor and wood chips was loaded in a 10 litre capacity digester, equipped with a temperature control and 180 degrees of rotation, as shown in Figure 2. This wide rotation is required for better impregnation of cooking chemicals in the cell walls $(5-8 \mu \mathrm{m}$ thick) of the wood chips. $1 \mathrm{~kg}$ of the oven dried wood sample was subjected to cooking at a wood:liquor ratio of $1: 4,28 \%$ sulphidity $\left(\mathrm{Na}_{2} \mathrm{~S}\right.$ and $\mathrm{NaOH}$ expressed as $\mathrm{Na}_{2} \mathrm{O}$ ) and $20 \%$ active alkali (as $\mathrm{Na}_{2} \mathrm{O}$ ). Heartwood and sapwood chips were cooked separately for $3 \mathrm{~h}$ at temperatures of $140{ }^{\circ} \mathrm{C}$ and 165 ${ }^{\circ} \mathrm{C}$ (pressure of 5 and 8 bar, respectively), whereas the whole wood chips were subjected to kraft cooking only at $165{ }^{\circ} \mathrm{C}$ for $3 \mathrm{~h}$. After $3 \mathrm{~h}$, the pulp was separated from the black liquor and it was thoroughly washed with deionized water for 5-6 times to remove the residual black liquor adhered to the surface of the fibres. The pulp samples were dried at $103.5{ }^{\circ} \mathrm{C}$ in a hot air oven for $12 \mathrm{~h}$, prior to characterization. Around $15-20 \mathrm{~mL}$ of black liquor was collected from the bottom of the digester after $1 \mathrm{~h}, 2 \mathrm{~h}$ and $3 \mathrm{~h}$ of cooking time, as shown in Figure 2.

\section{Bleaching of pulp fibres}

The whole wood pulp (kraft cooked at $165^{\circ} \mathrm{C}, 3 \mathrm{~h}$ ), having a brightness of 19.4 and pulp viscosity of 681 $\mathrm{mL} / \mathrm{g}$, was subjected to the elemental chlorine free 
bleaching process. The bleaching process and the measurement of brightness (ISO 2474) and viscosity (SCAN C 15:62) were carried at the Central Pulp and Paper Research Institute, Saharanpur, India. The bleaching sequence of $\mathrm{OD}_{0} \mathrm{EopD}_{1} \mathrm{EpD}_{2}$ was followed. In this sequence, $\mathrm{O}$ corresponds to the oxygen stage, $\mathrm{D}_{0}$ stands for the first chlorine dioxide stage, Eop stands for the first alkaline extraction stage reinforced with oxygen and hydrogen peroxide, $\mathrm{D}_{1}$ stands for the second chlorine dioxide stage, Ep corresponds to the first alkaline extraction stage reinforced with hydrogen peroxide and $\mathrm{D}_{2}$ stands for the second chlorine dioxide stage. The bleaching parameters for all the stages are described in Table 1 and the corresponding brightness and viscosity of the pulps are shown in Table 2 .

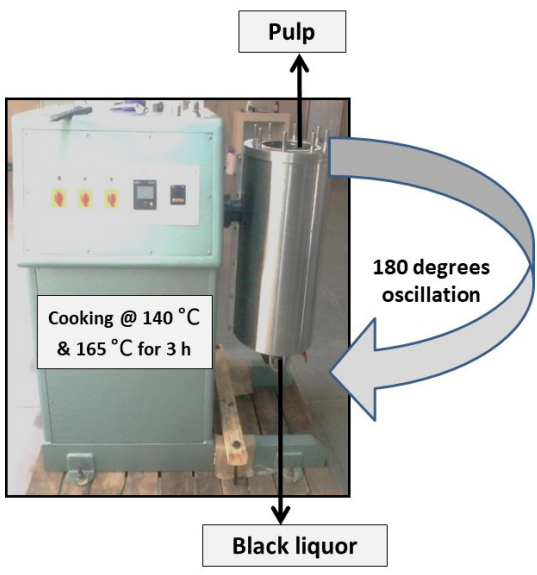

Figure 2: Rotary pulp digester used for kraft cooking of wood chips at two different temperatures of $140{ }^{\circ} \mathrm{C}$ and $165^{\circ} \mathrm{C}$

Table 1

Parameters used in bleaching of whole wood pulp

\begin{tabular}{lcccccc}
\hline Parameter & $\mathrm{O}$ & $\mathrm{D}_{0}$ & Eop & $\mathrm{D}_{1}$ & $\mathrm{Ep}$ & $\mathrm{D}_{2}$ \\
\hline $\mathrm{pH}$ & $11-12$ & 2.4 & 11.0 & 2.5 & 11.0 & $3-4$ \\
Pulp consistency $(\%)$ & 10 & 5 & 10 & 10 & 10 & 10 \\
$\mathrm{O}_{2}$ pressure $\left(\mathrm{kg} / \mathrm{cm}^{2}\right)$ & $5-6$ & - & 2.5 & - & - & - \\
Temperature $\left({ }^{\circ} \mathrm{C}\right)$ & 105 & 55 & 68 & 80 & 66 & 80 \\
\hline
\end{tabular}

O: oxygen, D: chlorine dioxide, E: alkaline extraction, P: hydrogen peroxide

Table 2

Brightness and viscosity of unbleached and bleached pulps

\begin{tabular}{lcccccc}
\hline Parameter & Unbleached & $\mathrm{O}$ & Eop & $\mathrm{D}_{1}$ & $\mathrm{Ep}$ & $\mathrm{D}_{2}$ \\
\hline Brightness (\% ISO) & 19.4 & 29.9 & 61 & 78.3 & 83.2 & 85.2 \\
Pulp viscosity (mL/g) & 681 & 632 & 598 & 560 & 495 & 465 \\
\hline : & oxygen, D: chlorine dioxide, E: alkaline extraction, P: hydrogen peroxide
\end{tabular}

\section{Pulp analysis}

The pulps subjected to cooking and bleaching were characterised with regard to the water retention value (WRV), ash content, cellulose content and Klason lignin content, as well as by using optical microscopy and thermogravimetric analysis (TGA). A brief description of these techniques is given below.

\section{Water retention value}

The water retention value (WRV) was determined by the procedure of TAPPI standard-UM 256. The whole wood, heartwood and sapwood samples of $5 \mathrm{~g}$ each were placed in plastic vials and $15 \mathrm{~mL}$ of deionized water were added. The samples were placed into a refrigerated centrifuge $\left(2600 \mathrm{rpm}, 25^{\circ} \mathrm{C}\right.$ for 30 min). After centrifuging, the wet pulp samples were separated from the liquid using Whatman filter paper and then oven dried at $103.5{ }^{\circ} \mathrm{C}$ till constant weight was attained. The WRV was calculated using the following equation:

WRV = (weight after centrifuging / weight after drying) -1 


\section{Ash content}

Ash represents the inorganic matter in the sample. The ash content in the wood or pulp samples was determined in accordance with TAPPI standard-T211, by incinerating $5 \mathrm{~g}$ of oven dried samples in a muffle furnace (Tempo TI-58HTB) at $525{ }^{\circ} \mathrm{C}(\sim 3 \mathrm{~h})$ until constant weight was attained. The $\%$ ash was calculated using the following equation:

$\%$ Ash $=$ (weight of ash / weight of oven dried sample $)$

$* 100$

\section{Klason lignin content}

Klason lignin content was determined following TAPPI T222 and TAPPI UM 250. At first, $0.15 \mathrm{~g}$ of oven dry sample was taken and ground to a uniform size. The weighed sample was added to $3 \mathrm{~mL}$ of $72 \%$ $\mathrm{H}_{2} \mathrm{SO}_{4}$ in a $50 \mathrm{~mL}$ conical flask, stirred thoroughly for uniform mixing and kept at $25{ }^{\circ} \mathrm{C}$ for $1 \mathrm{~h}$. After which, $84 \mathrm{~mL}$ of demineralized water was added to the sample and kept in the autoclave $\left(120^{\circ} \mathrm{C}\right)$ for $1 \mathrm{~h}$. After $1 \mathrm{~h}$, filtration was carried out to separate the solids from the liquid. The separated solids were dried overnight and weighed to give the Klason lignin content. The liquid was used to assess the amount of acid soluble lignin using a UV-visible spectrophotometer. $5 \mathrm{~mL}$ of $3 \%$ sulphuric acid was added to the filtrate and its absorbance at $205 \mathrm{~nm}$ was recorded. Finally, the soluble and insoluble lignin content was calculated as per Equations (3-6):

Total lignin = Insoluble lignin + Soluble lignin

Insoluble lignin content $(\%)=\left(\mathrm{W}_{\text {lignin }} / \mathrm{W}_{\text {fibre }}\right) * 100$ Soluble lignin content $(\%)=\left[\mathrm{CV} /\left(1000 * \mathrm{~W}_{\text {fibre }}\right)\right]^{* 100}$

(5)

where $\mathrm{C}=(\mathrm{A} / 110) *\left(\mathrm{~V}_{\text {final }} / \mathrm{V}_{\text {initial }}\right)$

$\mathrm{W}_{\text {lignin }}=$ oven-dry weight of the insoluble lignin or Klason lignin $(\mathrm{g}) ; \mathrm{W}_{\text {fibre }}=$ oven-dry weight of pulp $(\mathrm{g})$; $\mathrm{C}=$ concentration of soluble lignin in the filtrate $(\mathrm{g} / \mathrm{l})$; $\mathrm{V}=$ total volume of the filtrate $(\mathrm{mL}) ; \mathrm{A}=$ absorbance at a wavelength of $205 \mathrm{~nm} ; \mathrm{V}_{\text {final }}=$ final volume of the solution $(\mathrm{mL}) ; \mathrm{V}_{\text {initial }}=$ initial volume of the solution $(\mathrm{mL})$.

\section{Cellulose content}

The study indicates the amount of cellulose present in the wood or pulp. This process involves adding 15 $\mathrm{mL}$ acetic acid and $1.5 \mathrm{~mL}$ concentrated nitric acid to $\sim 1 \mathrm{~g}$ of sample, and refluxing for 20 minutes. The samples were then washed with ethanol and filtered using a cotton cloth, followed by oven drying for $12 \mathrm{~h}$. The resulting pulp was noted as material $\mathrm{A}$ and it was incinerated at $525^{\circ} \mathrm{C}$ in a muffle furnace until constant weight was attained, and the resulting pulp was noted as material B. The percentage of the cellulose in the sample was calculated as per Equation (7):

$\%$ Cellulose $=$ (weight of material $\mathrm{A}-$ weight of material B)/total weight of the sample

\section{Microscopic analysis}

This analysis reveals the structure of pulp fibres, namely tracheids, vessels and libriform fibres. An amount of $\sim 1 \mathrm{~g}$ pulp fibres was taken in a clean plastic vial and $2 \mathrm{~mL}$ of water was added to the sample and swirled, so that the pulp fibres were thoroughly spread. The wet pulp slurry was poured on a clean glass slide, the excess water was removed using blotting paper and the pulp was allowed to dry. Imaging of individual pulp fibres was carried out using a microscope (Olympus SZ17, in the reflectance mode).

\section{Thermogravimetric analysis (TGA)}

This analysis was carried out on a Shimadzu DTG60 to determine the thermal stability of the fibres after cooking and bleaching. Tests were carried out from $20{ }^{\circ} \mathrm{C}$ to $600{ }^{\circ} \mathrm{C}$ at a heating rate of $20{ }^{\circ} \mathrm{C} / \mathrm{min}$ under nitrogen atmosphere. Around $5 \mathrm{~g}$ of heartwood, sapwood, bleached and unbleached whole wood pulp samples were used to obtain the \% weight reduction versus temperature plots.

\section{Brightness}

Brightness was determined in accordance with ISO 2474. The brightness test should be able to measure the effect of bleaching and the amount of coloured substances in the pulp. This is determined by taking reflectance readings at $457 \mathrm{~nm}$ wavelengths of light. Brightness is measured as the reflectance value (relative to magnesium oxide standard) in the blue region of the visible spectrum.

\section{Viscosity}

Viscosity tests were carried out according to SCAN C 15:62. The solution viscosity of a pulp gives an indication of the average degree of polymerization of cellulose. The viscosity of $0.5 \%$ cellulose solutions was determined using $0.5 \mathrm{M}$ cupriethylene diamine (CED) as a solvent and a capillary viscometer.

\section{Black liquor analysis by UV-visible spectroscopy}

UV-visible spectroscopy characterization was performed on a Hitachi U2900 for all (whole wood, heartwood and sapwood) the black liquor solutions collected at different time intervals ( $1 \mathrm{~h}, 2 \mathrm{~h}$ and $3 \mathrm{~h}$ ) from the bottom of the digester to check the presence of lignin derivatives. The main purpose of the UV analysis was to search for the lignin peak (phenolic groups) and qualitatively confirm its presence, as the absorbance is directly proportional to the purity level of lignin. The absorption spectra were recorded between 190 to $400 \mathrm{~nm}$ wavelengths. Generally, kraft lignin has its spectrum at wavelengths of 205-210 nm, and the appearance of two characteristic peaks in the lignin spectrum is due to non-condensed phenolic groups (aromatic ring). The spectrum was determined by diluting $0.1 \mathrm{~mL}$ of black liquor solution in $19 \mathrm{~mL}$ of water for the whole wood and heartwood, and $0.01 \mathrm{~mL}$ 
of black liquor solution in $20 \mathrm{~mL}$ of water for sapwood.

\section{RESULTS AND DISCUSSION}

The composition differences, temperature variations and cooking time play a vital role in the delignification process. In this study, a cooking time of $3 \mathrm{~h}$ was kept constant and the comparison was made between sapwood and heartwood, as well as with regard to different temperatures (165 ${ }^{\circ} \mathrm{C}$ and $140{ }^{\circ} \mathrm{C}$ ). As a result of cooking, a pulp with high cellulose content and high porosity (increased number of small pores in the lignin matrix), with minimal damage to cell wall layers, was obtained. A better understanding of the kinetics of lignin degradation in the whole wood, as well as in heartwood and sapwood, is important for potential improvements in the pulping process of subabul wood. So, the pulps were characterised before and after lignin degradation (cooking and bleaching). The characterization data of the wood chips and the pulps are presented in Tables 3 and 4 , respectively.

Figure 3 presents images of oven dried pulp from all the samples obtained after cooking (Fig. $3 \mathrm{~b}$ was taken after cooking and bleaching). It can be observed from Figure 3 (a, c and e) that the separation of individual fibres is evident in all three unbleached samples, i.e. whole wood, heartwood and sapwood pulps, obtained after cooking at $165{ }^{\circ} \mathrm{C}$. At $140{ }^{\circ} \mathrm{C}$ cooking temperature, the chips are mostly intact, as shown in Figure $3 \mathrm{~d}$ and $3 \mathrm{f}$, indicating insufficient cooking, which was also reported by Lourenco et $a l .{ }^{20}$ Fibre peeling on both surfaces and surface fibrillation (Fig. 3d-3f) indicates that middle lamella lignin is degraded, but the degradation has not percolated in the thickness direction due to the temperature induced diffusional constraints. Also, longitudinal breakage of the chips, owing to the application of shear force, was observed in the case of sapwood pulp cooked at $140{ }^{\circ} \mathrm{C}$. At both temperatures, sapwood pulp exhibited better fibre separation, in comparison with heartwood pulp, because sapwood has less lignin and less extractives compared to heartwood. ${ }^{27}$ As expected, bleached pulp fibres (Fig. 3b) are collapsed and entangled to each other due to the higher amount of cellulose. The mass loss of the samples during cooking is mainly caused by the removal of extractives, dissolution of low molecular weight carbohydrates and lignin. ${ }^{20}$ At both temperatures $\left(140{ }^{\circ} \mathrm{C}, 165{ }^{\circ} \mathrm{C}\right)$ sapwood presented $20 \%$ higher pulping yields, compared to heartwood. The yield differences were expected, owing to the lower cellulose content, and higher extractives and lignin content reported for heartwood, compared to sapwood, as shown in Table 3. A few authors (Morais et al., ${ }^{22}$ Miranda et al. $^{23}$ ) also reported a similar difference in pulp yields for Eucalyptus globulus heartwood and sapwood.

The data obtained for sapwood and heartwood chips (prior to cooking) in comparison with the pulps cooked at $165{ }^{\circ} \mathrm{C}$ exhibited a significant difference in lignin content, indicating the effect of the selected cooking parameters. From the comparison of the pulps cooked at $165{ }^{\circ} \mathrm{C}$, bleached whole wood, unbleached sapwood and unbleached heartwood pulps have exhibited $0.8 \%$, $1.3 \%$ and $2.8 \%$ (kappa number of 5,9 and 19) of residual lignin, respectively. This could be attributed to the fact that heartwood has ray parenchyma cells, which are mostly filled with phenolic extractives, ${ }^{7}$ which were also found to have a negative impact during pulping by increasing chemical consumption and pitch deposits. ${ }^{20-21}$ Residual lignin in the pulp generally contains fewer $\beta$-O-4 linkages, condensed carboncarbon and lignin-carbohydrate linkages, which are oxidized and solubilised during the elemental chlorine free bleaching process, thus resulting in negligible lignin content in bleached pulps.

Table 3

Characterization data of wood chips (prior to cooking)

\begin{tabular}{lccccc}
\hline Wood sample & $\begin{array}{c}\text { Lignin } \\
\text { content }(\%)\end{array}$ & $\begin{array}{c}\text { Kappa } \\
\text { number }\end{array}$ & $\begin{array}{c}\text { Cellulose } \\
\text { content }(\%)\end{array}$ & $\begin{array}{c}\text { Water retention } \\
\text { value }\end{array}$ & $\begin{array}{c}\text { Ash/Inorganic } \\
\text { content }(\%)\end{array}$ \\
\hline Heartwood chips & $35.3 \pm 0.1$ & $238 \pm 0.6$ & $51.4 \pm 0.2$ & $1.1 \pm 0.2$ & $1.32 \pm 0.11$ \\
Sapwood chips & $27.6 \pm 0.2$ & $186 \pm 1.3$ & $61.8 \pm 0.1$ & $1.4 \pm 0.4$ & $1.85 \pm 0.03$ \\
\hline
\end{tabular}




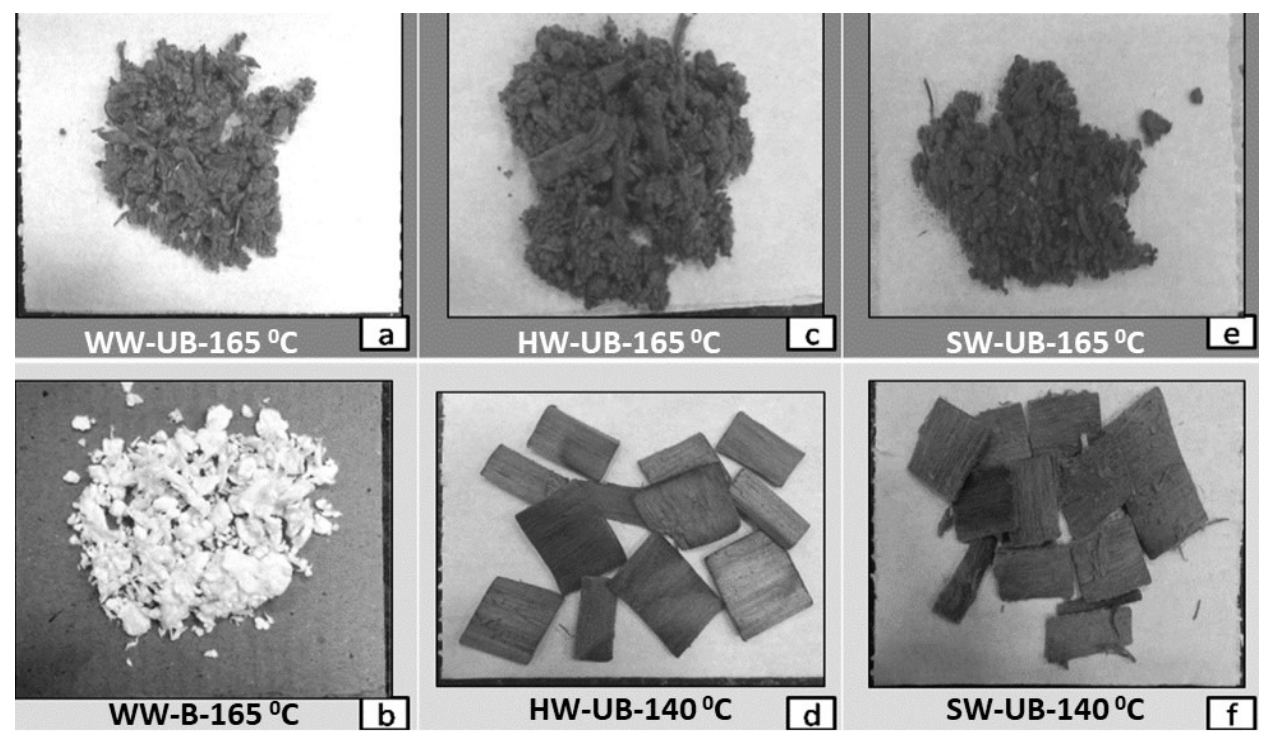

Figure 3: Images of pulp fibres obtained after kraft cooking (WW - whole wood, HW - heartwood, SW - sapwood, UB - unbleached, B - bleached)

Furthermore, there is a significant difference between the unbleached pulp samples when temperature is taken into consideration, i.e. the residual lignin content is $93-96 \%$ lower for the pulps cooked at $165{ }^{\circ} \mathrm{C}$, compared to the pulps cooked at $140{ }^{\circ} \mathrm{C}$. At $140{ }^{\circ} \mathrm{C}$, only primary peeling of reducing end groups takes place, whereas increasing temperature accelerates the reactivity and depolymerisation of lignin. The degradation and dissolution of hemicelluloses at $140{ }^{\circ} \mathrm{C}$ also contributes to the partial removal of lignin from the cell wall (inducing porosity) and compound middle lamella. As the porosity of cell wall increases, the diffusion of lignin degradation products from the cell wall to the cooking liquor becomes easier with increasing temperature.

It has been found by the determining the cellulose content that the \% cellulose content of sapwood is by $\sim 10 \%$ higher than that of heartwood for both temperatures. The higher the lignin removal, the higher is the $\%$ cellulose content of the pulp, because cellulose and lignin are intermingled and intertwined in the cell wall layers. The bleached whole wood pulp with negligible lignin content exhibited the highest $\%$ cellulose content (92\%) among the pulp samples. The density of sapwood is lower, because of the absence of extractives and tyloses, which may have been infiltrated into heartwood with the increase in age, due to which sapwood is found to have high cellulose content with less lignin and lipophilic extractives. ${ }^{28}$ Also, the \% cellulose content is $\sim 50 \%$ higher for the pulps processed at
$165{ }^{\circ} \mathrm{C}$ than for those cooked at $140{ }^{\circ} \mathrm{C}$, because pulping at $140{ }^{\circ} \mathrm{C}$ corresponds to the removal of extractives, acetyl groups and uronic acids from hemicelluloses, as well as to a partial dissolution of lignin by cleavage of $\alpha$ and $\beta$-arylether linkages in the phenolic units. Meanwhile, at $165{ }^{\circ} \mathrm{C}$ (bulk delignification stage), most of the lignin from the compound middle lamella/cell wall layer is dissolved and alkaline hydrolysis of glycosidic bonds also takes place, thus reducing the residual lignin content to $<3 \%$ in all the pulps.

The water retention value (WRV) is a qualitative analysis, which gives the water absorption capacity and the amount of lignin present in the pulp as it measures fibre swelling. WRV should increase with the removal of lignin, as it is hydrophobic in nature. Therefore, high WRV indicates greater removal of lignin from the wood cell interfaces (compound middle lamella). It is observed that WRV of sapwood is higher than that of heartwood at both temperatures, and also the values at $165{ }^{\circ} \mathrm{C}$ are higher than at $140{ }^{\circ} \mathrm{C}$, as shown in Table 4. From an anatomical point of view, the extractive components are higher in heartwood than in sapwood. ${ }^{29}$ Hence, the impregnation of cooking chemicals is difficult in heartwood because of the small pore sizes, deposition of extractives in the pit membranes and the presence of tyloses. ${ }^{30-31}$

Due to the above composition differences and lower cooking time $\left(140{ }^{\circ} \mathrm{C}\right)$, the WRV of heartwood pulp at $140{ }^{\circ} \mathrm{C}$ is found to have the lowest value (1.4), compared to the other pulp 
samples, and this is in line with its higher residual lignin content $(31 \%) .{ }^{32}$ In contrast, the bleached pulp is found to have a high WRV (21.2), because it has high porosity and negligible residual lignin, which enables it to retain a higher amount of liquid than unbleached pulp (WRV of 15.3).

Ash is an indication of the amount of inorganics present in the sample. The pulp ash also depends on the conditions and severity of the pulping process. ${ }^{33-34}$ The low lignin content and high amounts of inorganics enable sapwood pulp to have high ash content (Tables 3-4). ${ }^{35}$ During the incineration process, the pulp loses its mass at temperatures above $300{ }^{\circ} \mathrm{C}$, indicating degradation or modification of hemicelluloses, amorphous cellulose and lignin, and also the evaporation of liquid extractives. ${ }^{36}$ The combustion of the cellulose-lignin composite structure continues to take place until $900{ }^{\circ} \mathrm{C}$, whereas the decomposition of cellulose alone ends at $400{ }^{\circ} \mathrm{C}$, because it burns continuously due to the absence of interfaces. The bleached whole wood pulp has exhibited low ash \% (1.2\%), as it contains only cellulose and negligible amounts of lignin or other aromatic extractives. The $\%$ ash content of the wood chips is $<2 \%$. The $\%$ ash content of the pulp cooked at $140{ }^{\circ} \mathrm{C}$ is $<26 \%$, whereas the value reaches $>30 \%$ for the pulps cooked at $165{ }^{\circ} \mathrm{C}$. As shown in Figure 4 , the residue is white in colour for ash contents $<2 \%$, but the residue turns black for ash content above $20 \%$. This reminds the oxidation of PAN fibres around $250{ }^{\circ} \mathrm{C}$ during carbon fibre production, which is a necessary step because oxidation increases the thermal stability by increasing C-C bonds or cyclic groups (turning white fibre into black fibre). If the lignin content is very high, as in the wood chips, or if the lignin content is very low, as in the bleached pulps (collapsed fibres), the $\%$ of the interfacial pore area becomes very low, which allows complete degradation of cellulose/hemicellulose/lignin, leaving only inorganics. If the lignin content is medium, as in the unbleached pulps, the $\%$ of interfacial pore area becomes very high, which allows slow evaporation of extractives, slower degradation of lignin fragments, giving enough heat and time, so that cellulose can oxidise and form cyclic rings, which can be noticed by observing black coloured pulp, as shown in Figure 4a. The ash/inorganic content is also higher for the pulps cooked at 165 ${ }^{\circ} \mathrm{C}$, compared to the pulps cooked at $140{ }^{\circ} \mathrm{C}$, due to the increased interfacial pore area. Optical microscopy images of pulp fibres after cooking and bleaching are shown in Figure 5. The extent of delignification and separation of the wood chips into individual pulp fibres can be qualitatively compared based on the microscopic images. ${ }^{37}$ For the kraft pulps obtained at $165{ }^{\circ} \mathrm{C}$, individual fibres due to degradation of middle lamella are observed for both heartwood and sapwood pulps (Fig. 5c, 5e). The loose network structure is due to the entanglement of individual fibres, resulting from drying of the low consistency wet slurry. Between sapwood and heartwood pulps, better separation of libriform fibres and tracheids is evident in sapwood pulps. The concentration of locally deposited phenolic extractives in vessels is found to be higher in heartwood pulps. For the kraft pulps obtained at $140{ }^{\circ} \mathrm{C}$ (Fig. 5d, 5f), peeling of fibre bundles is observed only on the surface of the sample. Between the two pulps, the surface looks denser in heartwood pulps; wherein tracheids, vessels and libriform fibres are not well separated compared to sapwood pulps. Kinks, followed by slight fibre peeling on surface fibres, can be observed in the case of heartwood pulps.
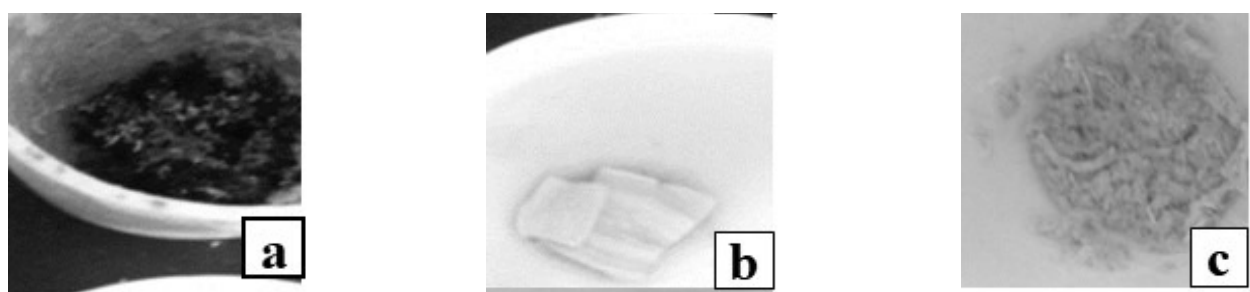

Figure 4: Ash obtained from unbleached pulp fibres (a), wood chips (b) and bleached pulp fibres (c) 
Table 4

Characterization data of pulp (after cooking at two different temperatures)

\begin{tabular}{|c|c|c|c|c|c|c|}
\hline Pulp sample & $\begin{array}{l}\text { Cooking } \\
\text { temperature }\end{array}$ & $\begin{array}{l}\text { Residual lignin } \\
\text { content }(\%)\end{array}$ & $\begin{array}{l}\text { Kappa } \\
\text { number }\end{array}$ & $\begin{array}{c}\text { Cellulose } \\
\text { content }(\%)\end{array}$ & $\begin{array}{l}\text { Water retention } \\
\text { value }\end{array}$ & $\begin{array}{c}\text { Ash/Inorganic } \\
\text { content }(\%)\end{array}$ \\
\hline Whole wood pulp - unbleached & $165^{\circ} \mathrm{C}$ & $1.6 \pm 0.3$ & $11 \pm 2$ & $74.2 \pm 1.2$ & $15.3 \pm 0.2$ & $36.2 \pm 2$ \\
\hline Whole wood pulp - bleached & $165^{\circ} \mathrm{C}$ & $0.8 \pm 0.1$ & $5 \pm 0.6$ & $92 \pm 0.1$ & $21.2 \pm 0.1$ & $1.2 \pm 1.5$ \\
\hline \multirow{2}{*}{ Heartwood pulp-unbleached } & $140{ }^{\circ} \mathrm{C}$ & $31 \pm 0.2$ & $208 \pm 1.3$ & $44.5 \pm 1.5$ & $1.4 \pm 0.4$ & $21.8 \pm 1.0$ \\
\hline & $165^{\circ} \mathrm{C}$ & $2.8 \pm 0.3$ & $19 \pm 2$ & $71.2 \pm 1.7$ & $14.3 \pm 0.7$ & $29.8 \pm 0.3$ \\
\hline \multirow{2}{*}{ Sapwood pulp-unbleached } & $140^{\circ} \mathrm{C}$ & $20 \pm 0.4$ & $135 \pm 2.6$ & $49.1 \pm 3.0$ & $1.7 \pm 0.4$ & $25.9 \pm 0.7$ \\
\hline & $165^{\circ} \mathrm{C}$ & $1.3 \pm 0.1$ & $9 \pm 0.6$ & $80.1 \pm 2.0$ & $17.3 \pm 0.2$ & $36.6 \pm 0.6$ \\
\hline
\end{tabular}

Note that only whole wood was bleached
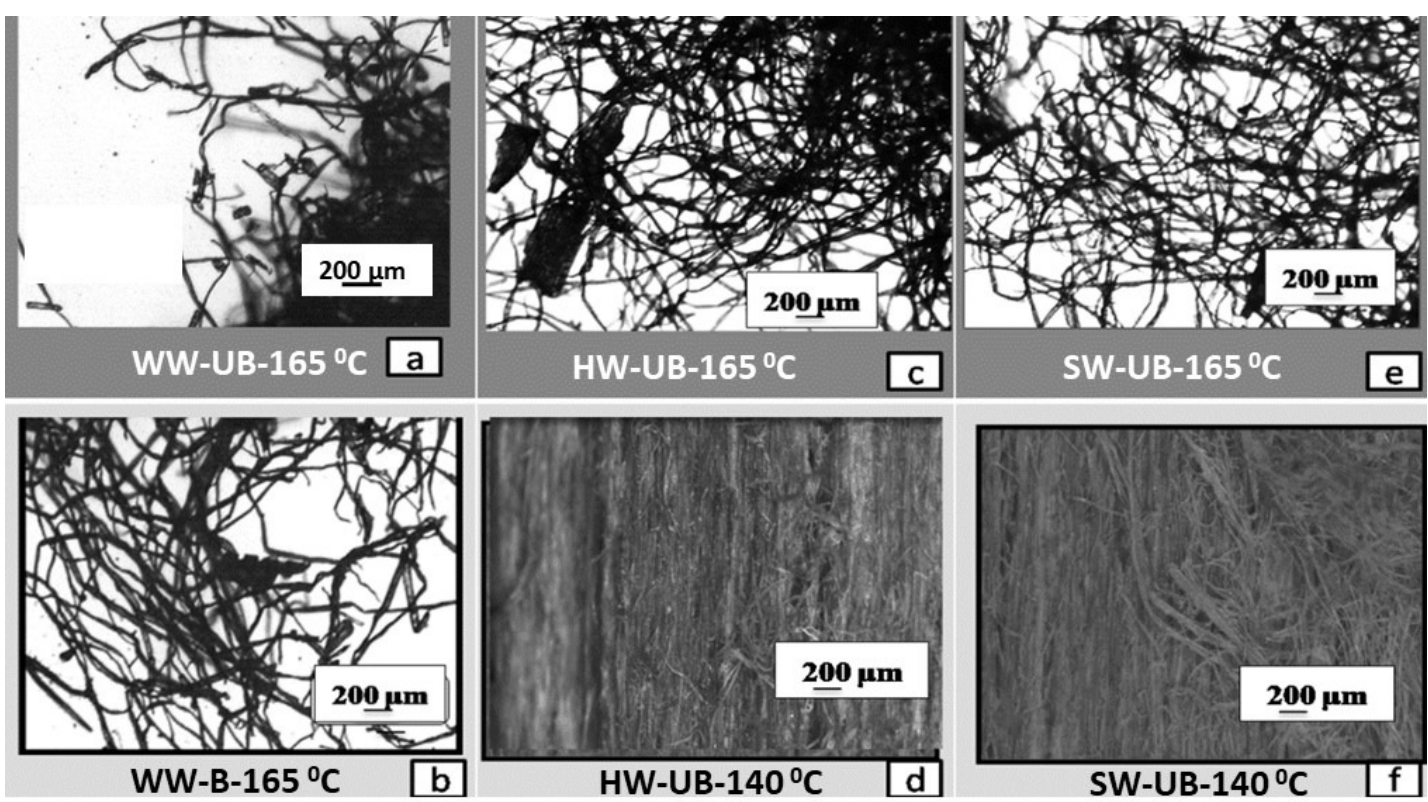

Figure 5: Optical images of pulp fibres. Note that the cooking temperature of $165^{\circ} \mathrm{C}$ resulted in loose single fibres (WW - whole wood, HW - heartwood, SW - sapwood, UB unbleached, B - bleached) 
The bleached kraft pulp (Fig. 5b) contains loose and collapsed fibres, with noticeable fibre fractures and twists at random points. Bleached fibres form a strong network structure with intermingled libriform fibres and tracheids of smooth individual fibres, but they are free from vessels. The images shown in Figure 5a-5f seem to confirm the effectiveness of cooking temperature and bleaching.

Thermogravimetric analysis (TGA) has been carried out to investigate the thermal degradation behaviour of heartwood and sapwood pulps, as well as bleached and unbleached whole wood pulp. In TGA analysis, it is widely reported that the primary thermal decomposition of cellulosic material occurs between $200{ }^{\circ} \mathrm{C}$ and $400{ }^{\circ} \mathrm{C}$, while the initial decomposition takes place in the amorphous regions. ${ }^{38-39}$ From the data shown in Figure 6 , the main degradation step $\left(\mathrm{T}_{\max }\right.$ corresponds to a huge weight loss) is found between $300{ }^{\circ} \mathrm{C}$ and $350{ }^{\circ} \mathrm{C}$ for bleached whole wood pulp, and from $250{ }^{\circ} \mathrm{C}$ to $300{ }^{\circ} \mathrm{C}$ for unbleached whole wood pulp. Also, the thermal stability of the bleached pulp is found to be very low (between $380{ }^{\circ} \mathrm{C}$ and $600{ }^{\circ} \mathrm{C}$ ), compared to unbleached pulp. The kraft cooking and bleaching processes have degraded the amorphous lignin matrix from middle lamella and cell walls, respectively, leaving collapsed cellulose fibres of moderate crystallinity. Hence, bleached fibres were thermally stable until $300{ }^{\circ} \mathrm{C}$, but thereafter a sharp reduction in their weight from $95 \%$ to $18 \%$ was observed with the increase in temperature from 300 to $380{ }^{\circ} \mathrm{C}$. The second sigmoid (in the case of bleached pulp) could be due to the absence of lignin and also to the absence of composite structure with micron size pores, acting as heat shields. Similarly, the overall weight loss of $38 \%$ (second sigmoid) in the case of unbleached pulp could be due to the presence of thermally stable composite structural units of residual lignin, which forms complexes with polysaccharides especially in cell walls. These unbleached pulps have changed colour at around $320{ }^{\circ} \mathrm{C}$, mostly turning into a charcoal structure with a huge number of $\mathrm{C}-\mathrm{C}$ bonds, which makes these pulps thermally stable up to $600{ }^{\circ} \mathrm{C}$.

Meanwhile, for the sapwood and heartwood pulps (Fig. 6b), the degradation temperature was between $284{ }^{\circ} \mathrm{C}$ and $315{ }^{\circ} \mathrm{C}$, and the overall weight loss was of $42 \%$ for heartwood and $36 \%$ for sapwood (second sigmoid), and it could be due to the heterogeneity of the micro-pores existing in the cell wall composite. As described previously, sapwood pulp has a higher water retention capacity due to its high cell wall porosity and high cellulose content, so the weight loss is high for sapwood pulp in comparison with heartwood pulp at around $100{ }^{\circ} \mathrm{C}$. Considering the degradation temperatures, the maximum weight loss can be attributed to the degradation of hemicelluloses and partial degradation of lignin. Like the unbleached whole wood, both sapwood and heartwood changed their colour at around 320 ${ }^{\circ} \mathrm{C}$, forming a cyclic structure with $\mathrm{C}-\mathrm{C}$ bonds, resembling a charcoal. Between $380{ }^{\circ} \mathrm{C}$ and 600 ${ }^{\circ} \mathrm{C}$, the unbleached whole wood, heartwood and sapwood pulps exhibited very little weight loss, due to the presence of the cell wall composite structure, low molecular weight extractives and inorganic fragments.

The brown colour of the unbleached pulp (whole wood) has lower brightness, as shown in Table 2. This could due to the presence of residual lignin, whose colour originates from different oxidised structures. ${ }^{40}$ Oxidative mechanisms are believed to convert part of the lignin's phenolic groups to quinone-like substances, which are known to absorb light. Oquinones have the strongest impact on the colour of lignin. The bleached pulps have exhibited a brightness of $85 \%$, which is $>400 \%$ higher than that of the unbleached pulps. The bleaching of fibres with chlorine dioxide and oxygen involves a radical reaction mechanism that targets phenolic and non-phenolic structures (lignin), resulting in a higher brightness value. Meanwhile, bleaching of fibres with peroxide involves a nucleophilic reaction mechanism that targets electrophilic carbon atoms, such as carbonyl structures $(\mathrm{C}=\mathrm{O})$ [lignin, extractives], resulting in a brightening effect and oxidation of lignin. Viscosity is a control parameter of pulp strength. The decrease in molar mass of the wood polymers during chemical degradation is normally estimated by measuring the intrinsic (limiting) viscosity of dissolved pulp fibres. Here, lignin degradation and dissolution during pulping and bleaching cause reduction in the viscosity of pulp. ${ }^{41}$ Lower viscosities in the range of $560 \mathrm{~mL} / \mathrm{g}$ correspond to pulp containing more degraded cellulose. The reduction in viscosity values (Table 2) from 681 $\mathrm{mL} / \mathrm{g}$ (unbleached) to $465 \mathrm{~mL} / \mathrm{g}$ (bleached) could be explained by the dissolution of amorphous cellulose molecules, consisting of shorter chains, depolymerisation of hemicelluloses, as well as by complete degradation of lignin during the last stages of the bleaching process. 

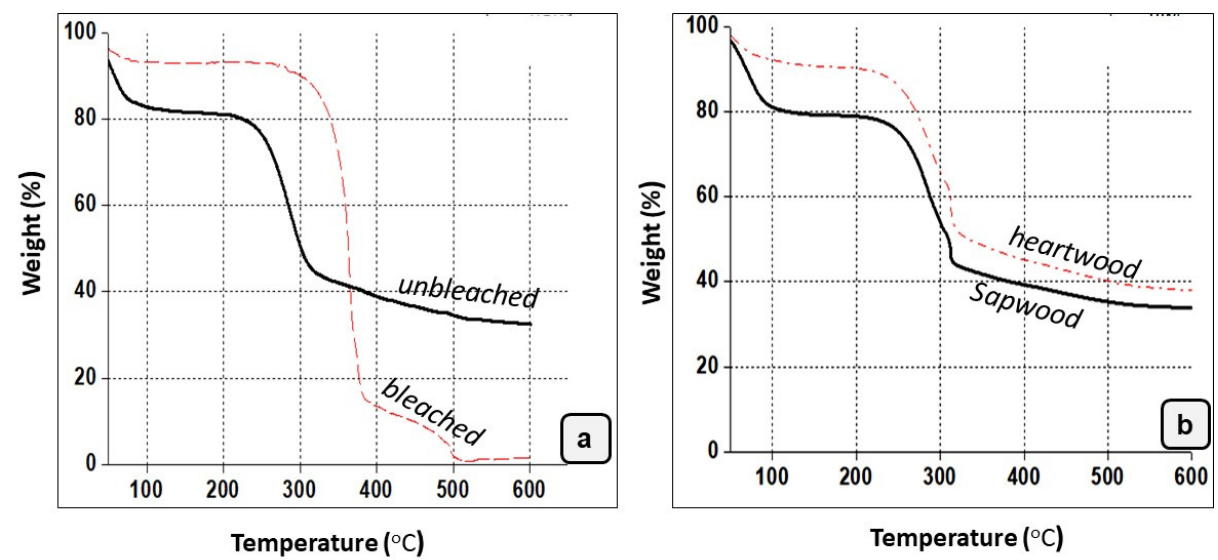

Figure 6: TGA curves of bleached and unbleached whole wood pulp fibres (a) and of heartwood and sapwood pulp fibres (b) obtained after kraft cooking at $165^{\circ} \mathrm{C}$ for $3 \mathrm{~h}$

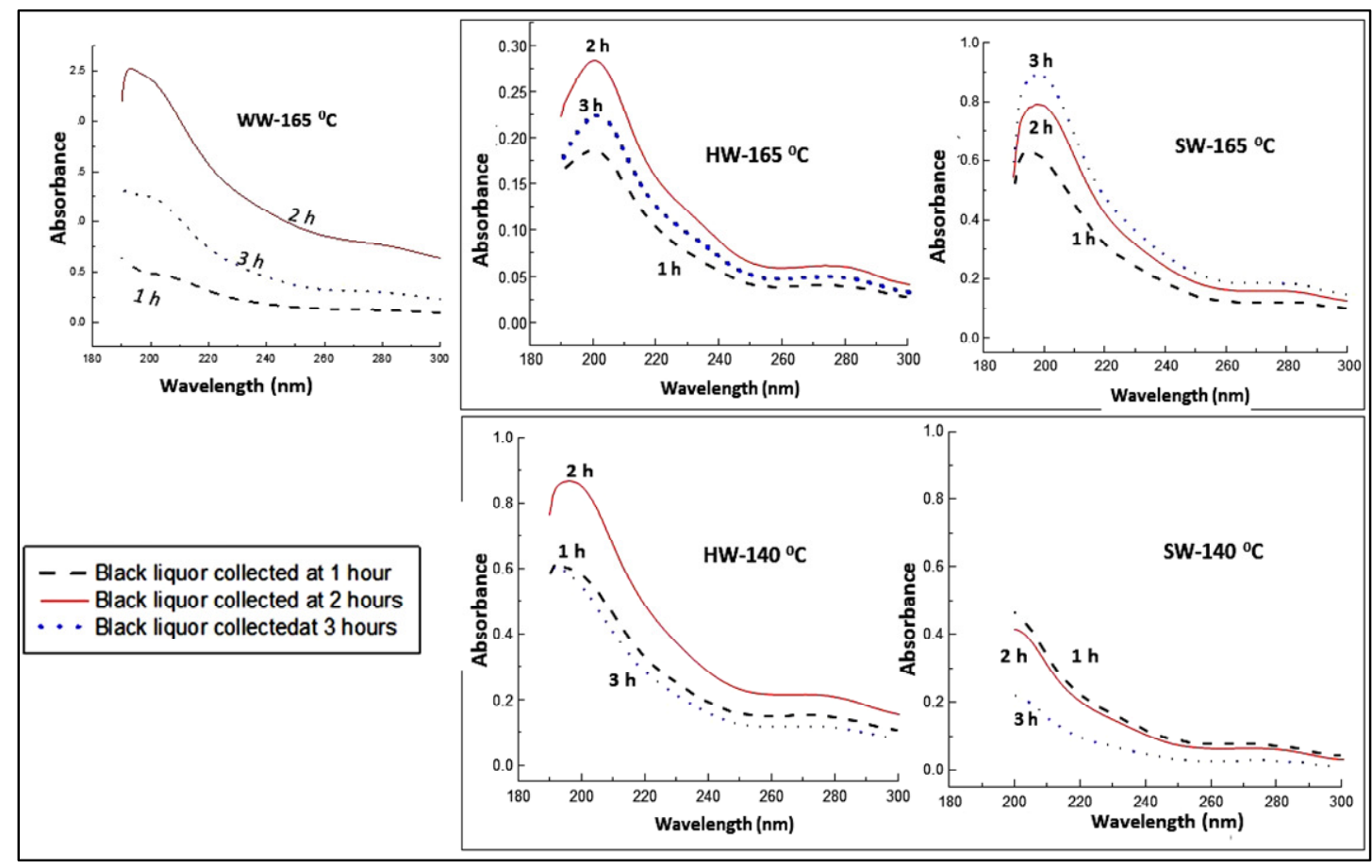

Figure 7: UV-Vis spectra of black liquor collected after $1 \mathrm{~h}, 2 \mathrm{~h}$ and $3 \mathrm{~h}$ (WW - whole wood, HW - heartwood, SW sapwood, UB - unbleached, B - bleached) 
From UV-Vis spectroscopic analysis (Fig. 7), significant lignin peaks were observed in all the samples, indicating effective transfer of lignin molecules from the wood chips to the black liquor. The absorbance at 200-205 $\mathrm{nm}$ indicates $\pi$ $\pi^{*}$ transitions and it is characteristic of the resonating system of aromatic lignin building units and the absorbance of 1 at $200 \mathrm{~nm}$ represents phenols. Heartwood black liquor (at $165{ }^{\circ} \mathrm{C}$ and $140{ }^{\circ} \mathrm{C}$ ) exhibited peaks at $200 \mathrm{~nm}$ wavelength, with the highest absorbance at $2 \mathrm{~h}$ cooking time, indicating bulk delignification, i.e. a higher amount of lignin was removed from wood cell interfaces (compound middle lamella) at this stage. However, after $2 \mathrm{~h}$, a decrease in absorbance is observed. This could be due to the accumulation of extractives and lignin fragments, which restricts the impregnation of cooking chemicals into wood cells and cell walls. The sapwood black liquor (at $165{ }^{\circ} \mathrm{C}$ ) also showed peaks at $200 \mathrm{~nm}$ wavelength, with the highest absorbance for $3 \mathrm{~h}$ cooking time. However, at the cooking temperature of $140{ }^{\circ} \mathrm{C}$, high absorbance was observed for $1 \mathrm{~h}$ and $2 \mathrm{~h}$ cooking time for the same sapwood black liquor, indicating the degradation of lignin from cell interface layers is minimal for $2 \mathrm{~h}$ and $3 \mathrm{~h}$ cooking time. Here, the phenolic hydroxyl groups are ionized, due to which the absorption intensities change with respect to time and temperature. The appearance of minute concentrated peaks $(250-300 \mathrm{~nm})$ is due to the electronic transition in phenols during the delignification process. ${ }^{42}$ In contrast to heartwood and sapwood, the whole wood black liquor showed peaks at $195 \mathrm{~nm}$ wavelength, with the highest absorbance for $2 \mathrm{~h}$ cooking time.

\section{CONCLUSION}

The determination of Klason lignin revealed that heartwood pulp has $\sim 50 \%\left(140{ }^{\circ} \mathrm{C}\right)$ and $115 \% \quad\left(165{ }^{\circ} \mathrm{C}\right)$ higher residual lignin than sapwood pulp, indicating the influence of the heartwood fraction in lignin removal. The cellulose content of the pulp at $165^{\circ} \mathrm{C}$ was found to be by $60 \%$ (heartwood pulp) and 63\% (sapwood pulp) higher than the values reported at $140{ }^{\circ} \mathrm{C}$, indicating the influence of temperature in lignin removal. Also, a ten-fold increase in the water retention value was observed for both pulps at $165^{\circ} \mathrm{C}$, compared to the values reported at 140 ${ }^{\circ} \mathrm{C}$, again indicating the influence of temperature in lignin removal. Due to the high lignin content and low cellulose content, the water retention value of the heartwood pulp is $23 \%$ lower than that of the sapwood pulp. The ash content of the whole wood and of the bleached pulp was found to be $<2 \%$ (ash is white in colour), but the ash content of unbleached pulp was found to be greater than $>20 \%$ (ash is black in colour) and it should be called as inorganic content due to the presence of carbon. This difference could be due to the partial oxidation of the pulp and partial structural integrity of the unbleached pulp cell walls. The inorganic content was found to be higher for the sapwood pulp than for the heartwood pulp, which could be due to the lower amount of lignin and higher amount of minerals present in sapwood. The optical images revealed individual libriform fibres, tracheids and vessels in the pulps obtained at $165{ }^{\circ} \mathrm{C}$. However, for the pulps obtained at $140{ }^{\circ} \mathrm{C}$, a denser network of fibres still exists, which indicates partial removal of lignin from middle lamella. The bleached pulp has exhibited higher brightness $(85.2 \%)$, higher cellulose content $(92 \%)$, higher water retention value (21), lower pulp viscosity $(465 \mathrm{~mL} / \mathrm{g})$ and lower residual lignin content $(0.8 \%)$ or kappa number (5), compared to the unbleached pulp, indicating the effectiveness of the selected elemental chlorine free bleaching sequence. The bleached pulps also exhibited higher thermal stability than the unbleached pulps up to $300{ }^{\circ} \mathrm{C}$. Afterwards, the thermal stability of the bleached pulps rapidly decreases to a lower value (weight loss of $>95 \%$ ) by $500{ }^{\circ} \mathrm{C}$, whereas that of the unbleached pulps remains partially stable (weight loss of <70\%) until $600{ }^{\circ} \mathrm{C}$, indicating the applicability of these pulps in thermal packaging. The UV-visible spectroscopic data of heartwood black liquor (collected after $1 \mathrm{~h}, 2 \mathrm{~h}$ and $3 \mathrm{~h}$ ) revealed the highest absorbance for $2 \mathrm{~h}$ black liquor for both 140 and $165{ }^{\circ} \mathrm{C}$, indicating that most of the lignin is removed from the wood cells within $2 \mathrm{~h}$ of the cooking process, which was not the case for sapwood black liquor.

The study concludes that the rate of delignification (kraft cooking) is temperaturedependent, time-dependant and also dependent on the wood log area (heartwood and sapwood). Thus, it can be recommended to process sapwood at $165{ }^{\circ} \mathrm{C}$ for $3 \mathrm{~h}$, while for heartwood processing time should be restricted to $2 \mathrm{~h}$. It is also recommended to use unbleached pulps, which have an expected thermal stability of over $300^{\circ} \mathrm{C}$.

ACKNOWLEDGMENTS: The authors thank Central Pulp and Paper Research Institute (CPPRI), Saharanpur, UP, India, for extending 
their support in performing the bleaching process, and sincere thanks to technicians Mr. Raju, Mr. Appala Reddy and Mr. Bhaskar Raju (Central Analytical Laboratory, BITS Hyderabad Campus) for assisting in handling various equipment.

\section{REFERENCES}

R. B. Adusumalli, W. Mook, R. Passas, P. Schwaller and J. Michler, J. Mater. Sci., 45, 2558 (2010), https://doi.org/10.1504/IJMATEI.2014.060320

2 D. Feldman, M. Lacasse and L. M. Baznaczuk, Polym. Sci., 12, $271 \quad$ (1986), https://doi.org/10.1016/0079-6700(86)90002-X

J. E. Bailey and D. F. Ollis, "Biochemical Engineering Fundamentals", New York, McGraw-Hill, 1986, pp. 38-42. https://doi.org/10.1016/01683659(86)90022-2

4 H. Karlsson, "Fibre Guide - Fibre Analysis and Process Applications in the Pulp and Paper Industry", Sweden, AB Lorentzen \& Wettre, 2006, pp. 7-41, http://www.worldcat.org/oclc/185365503

5 R. Puntambekar, M. Pydimalla, S. Dinda and R. B. Adusumalli, J. Indian Acad. Wood Sci., 13, 8 (2016), https://doi.org/10.1007/s13196-016-0159-5

6 I. Pinto, H. Pereira and A. Usenius, Trees, 18, 284 (2004), https://doi.org/10.1007/s00468-003-0305-8

7 R. K. Bamber, Forestry Commission of New South Wales, Wood Technology and Forest Research Division, Beecrolt, Vol. 2, 1987, pp. 1-7, https://pdfs.semanticscholar.org/1a39/8c78b56f4783f3 1cebe8423dad7556bd532a.pdf

8 A. J. Panshin and C. D. Zeeuw, "Textbook of Wood Technology: Structure, Identification, Properties, and Uses of the Commercial Woods of the United States and Canada", New York, McGraw-Hill, 1980, pp. 4042, https://searchworks.stanford.edu/view/801946

9 G. Henriksson, E. Brannvall and H. Lennhol, in "Wood Chemistry and Wood Biotechnology", edited by M. Ek, G. Gellerstedt and G. Henriksson, Berlin, Walter de Gruyter, 2009, pp. 13-44, https://www.degruyter.com/viewbooktoc/product/4048 $\underline{8}$

${ }^{10}$ D. Fengel and G. Wegener (Eds.), "Wood: Chemistry, Ultrastructure, Reactions", Berlin, Walter de Gruyter, 1984, pp. 20-23, https://www.degruyter.com/view/product/10130

11 P. Saranpää and W. Höll, Trees, 3, 138 (1989), https://doi.org/10.1007/BF00226648

12 T. E. Timell, "Compression Wood in Gymnosperms”, Berlin, Springer, 1986, pp. 410-416, https://www.springer.com/in/book/9783540157151

13 J. Gominho and H. Pereira, Wood Fibre Sci., 32,
189

(2000),

https://wfs.swst.org/index.php/wfs/article/view/580

14 G. A. Smook, "Handbook for Pulp and Paper Technologists", Vancouver, Angus Wilde Publications, 1992

$\mathrm{pp}$.

74-79,

https://trove.nla.gov.au/work/22361628?q\&versionId= 34741612

15 J. R. Obst, Tappi J., 68, 100 (1985), https://www.fpl.fs.fed.us/documnts/pdf1985/obst85a.p $\underline{\mathrm{df}}$

16 T. Trung, G. Downes, R. Meder and B. Allison, $\begin{array}{llll}\text { Appita } & \text { J., } & \mathbf{6 8}, & 39\end{array}$ https://www.researchgate.net/publication/279323478 17 M. Cardoso, D. Oliveira and M. L. Passos, Fuel, 88 , 756

(2009),

https://doi.org/10.1016/jfuel2008.10.016

18 J. G. Speight, "Gasification of Unconventional Feedstocks", Waltham, Gulf Professional Publishing, 2014, pp. 26-27, https://www.elsevier.com/books/gasification-ofunconventional-feedstocks/speight/978-0-12-799911-1 19 R. Alen, in "Forest Products Chemistry", edited by J. Gullichsen and H. Paulapuro, TAPPI Press, 2000, pp.

$62-76$, https://imisrise.tappi.org/TAPPI/Products/02/FIN/0202 FIN03.aspx

20 A. Lourenco, J. Gominho and H. Pereira, J. Pulp Pap. Sci., 36, 63 (2010), https://doi.org/10.15376/biores.10.4.7808-7816

21 I. Miranda, J. Gominho, A. Lourenco and $\mathrm{H}$. Pereira, Appita J., 60, $485 \quad$ (2007). https://www.researchgate.net/publication/233401330

22 M. C. Morais and H. Pereira, Wood Sci. Technol., 46, 709 (2012), https://doi.org/10.1007/s00226-0110438-7

23 I. Miranda, J. Gominho, A. Loureno and H. Pereira, Can. J. For. Res., 36, 2675 (2006), https://doi.org/10.1139/x06-130

24 B. Esteves, J. Gominho, J. C. Rodrigues, I. Miranda and H. Pereira, J. Wood Chem. Technol., 25, 217 (2005), https://doi.org/10.1080/02773810500366656

25 Y. Atac and H. Eroglu, Turk. J. Agric. For., 37, 243 (2013), https://doi.org/10.3906/tar-1205-20

26 C. P. Neto, D. V. Evtuguin, F. P. Furtado and A. P. Mendes Sousa, Ind. Eng. Chem. Res., 41, 6200 (2002), https://doi.org/10.1021/ie020263x

27 A. Lourenco, J. Gominho and H. Pereira, J. Wood Sci., 57, 20 (2011), https://doi.org/10.1007/s10086010-1137-y

28 F. Bertaud and B. Holmbom, Wood Sci. Technol., 38, 245 (2004), https://doi.org/10.1007/s00226-004- 
MADHURI PYDIMALLA et al.

0241-9

${ }^{29}$ K. W. Britt, "Handbook of Pulp and Paper Technology", USA, Van Nostrand Reinhold Company, 1970 , pp. 37-38, https://trove.nla.gov.au/version/26387537

30 A. J. Stamm, Wood Fibre, 1, 263 (2004), https://wfs.swst.org/index.php/wfs/article/view/1632

31 J. A. Petty and R. D. Preston, in Procs. R. Soc., London, $\quad 1969, \quad$ pp. 137-151, https://doi.org/10.1098/rspb.1969.0016

32 W. E. Hillis, "Heartwood and Tree Exudates", Berlin, Springer-Verlag, 1987, pp. 180-191, https://www.springer.com/in/book/9783642725364

33 F. M. L. Souza, C. A. Sansigolo, C. H. Pupo and G.

C. Sereghetti, Cellulose Chem. Technol., 51, 347 (2017),

http://www.cellulosechemtechnol.ro/pdf/CCT34(2017)/p.347-353.pdf

34 N. Spanic, V. Jambrekovic and M. Klaric, Cellulose Chem. Technol., 52, $163 \quad$ (2018). http://www.cellulosechemtechnol.ro/pdf/CCT34(2018)/p.163-169.pdf

35 S. Mariani, M. Torres, A. Fernandez and E. Morales, Tappi J., $4, \quad 8 \quad$ (2005), https://imisrise.tappi.org/TAPPI/Products/05/FEB/05F EB08.aspx

36 Y. Haiping, Y. Rong, C. Hanping, H. L. Dong and Z. Chuguang, Fuel, 86, 1781 (2007), https://doi.org/10.1016/j.fuel.2006.12.013

37 L. Penin, V. Santos, J. C. Del Rio and J. C. Parajo, Bioresour. Technol, $281,269 \quad$ (2019), https://doi.org/10.1016/j.biortech.2019.02.098

38 T. Fisher, M. Hajaligol and B. Waymack, J. Anal. Appl. Pyrol., 2, $331 \quad$ (2002), https://doi.org/10.1016/S0165-2370(01)00129-2

39 M. M. Seyed and H. F. Moafi, J. Ind. Text., 37, 31 (2007), https://doi.org/10.1177/1528083707078196

40 R. Gallo, I. B. Pantuza, G. A. dos Santos, M. D. Vilela de Resende, A. Xavier et al., Ind. Crop. Prod., 123, 434

(2018),

https://doi.org/10.1016/j.indcrop.2018.07.016

41 D. Gavrilescu and A. C. Puitel, Cellulose Chem. Technol., 49, $341 \quad$ (2015), http://www.cellulosechemtechnol.ro/pdf/CCT34(2015)/p.341-346.pdf

42 M. Pydimalla, N. Sainath Reddy, S. Jayanty and R. B. Adusumalli, IPPTA, 28, 130 (2016), https://www.tib.eu/en/search/id/BLSE\%3ARN6077264 72/Pulp-and-Black-Liquor-Characterization-of-

Subabul/ 